\title{
Corrigendum: Dioscin Inhibits HSC-T6 Cell Migration via Adjusting SDC-4 Expression: Insights From iTRAQ-Based Quantitative Proteomics
}

\section{OPEN ACCESS}

Edited and reviewed by:

Ruixin Zhu,

Tongji University, China

*Correspondence:

Jinyong Peng

jinyongpeng2005@163.com

Specialty section:

This article was submitted to Gastrointestinal and Hepatic

Pharmacology,

a section of the journal

Frontiers in Pharmacology

Received: 08 August 2019

Accepted: 14 August 2019 Published: 18 September 2019

Citation:

Yin L, Qi Y, Xu Y, Xu L, Han X, Tao $X$, Song $S$ and Peng J (2019) Corrigendum: Dioscin Inhibits HSCT6 Cell Migration via Adjusting SDC-4 Expression: Insights From ITRAQBased Quantitative Proteomics.

Front. Pharmacol. 10:1036. doi: 10.3389/fphar.2019.01036

\section{Lianhong Yin, Yan Qi, Youwei Xu, Lina Xu, Xu Han, Xufeng Tao, Shasha Song and Jinyong Peng *}

College of Pharmacy, Dalian Medical University, Dalian, China

Keywords: cell migration, dioscin, hepatic stellate cells, iTRAQ, liver fibrosis, syndecan-4

\section{A Corrigendum on}

Dioscin Inhibits HSC-T6 Cell Migration via Adjusting SDC-4 Expression: Insights From iTRAQ-Based Quantitative Proteomics

By Yin L, Qi Y, Xu Y, Xu L, Han X, Tao X, Song S and Peng J (2017) Front. Pharmacol. 8:665. doi: 10.3389/fphar.2017.00665

In the original article, there was a mistake in Figure $\mathbf{6 A}$ as published. The authors inserted the wrong image in this figure part. In this corrigendum, we have furthermore provided the correct result of the shRNA+ dio $5.0 \mu \mathrm{g} / \mathrm{mL}$ group, which showed no influence on the results. The corrected Figure 6 appears below. The authors apologize for this error and state that this does not change the scientific conclusions of the article in any way. The original article has been updated.

Copyright (c) 2019 Yin, Qi, Xu, Xu, Han, Tao, Song and Peng. This is an open-access article distributed under the terms of the Creative Commons Attribution License (CC BY). The use, distribution or reproduction in other forums is permitted, provided the original author(s) and the copyright owner(s) are credited and that the original publication in this journal is cited, in accordance with accepted academic practice. No use, distribution or reproduction is permitted which does not comply with these terms. 
A

Control Non-specific shRNA

ShRNA

shRNA-Dio $5.0 \mu \mathrm{g} / \mathrm{mL}$
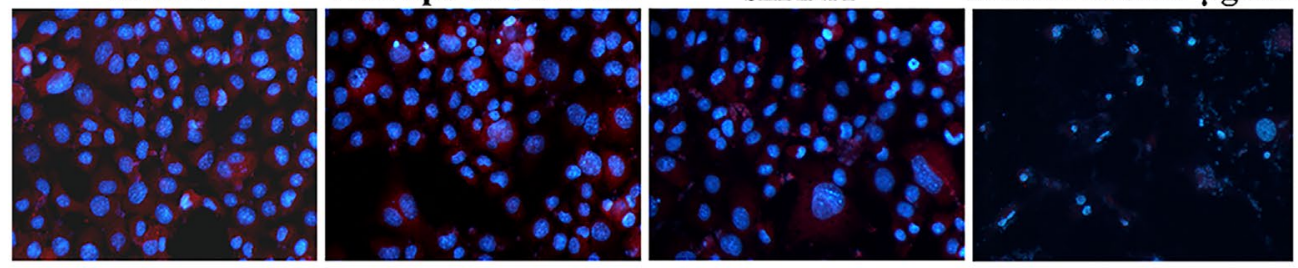

B
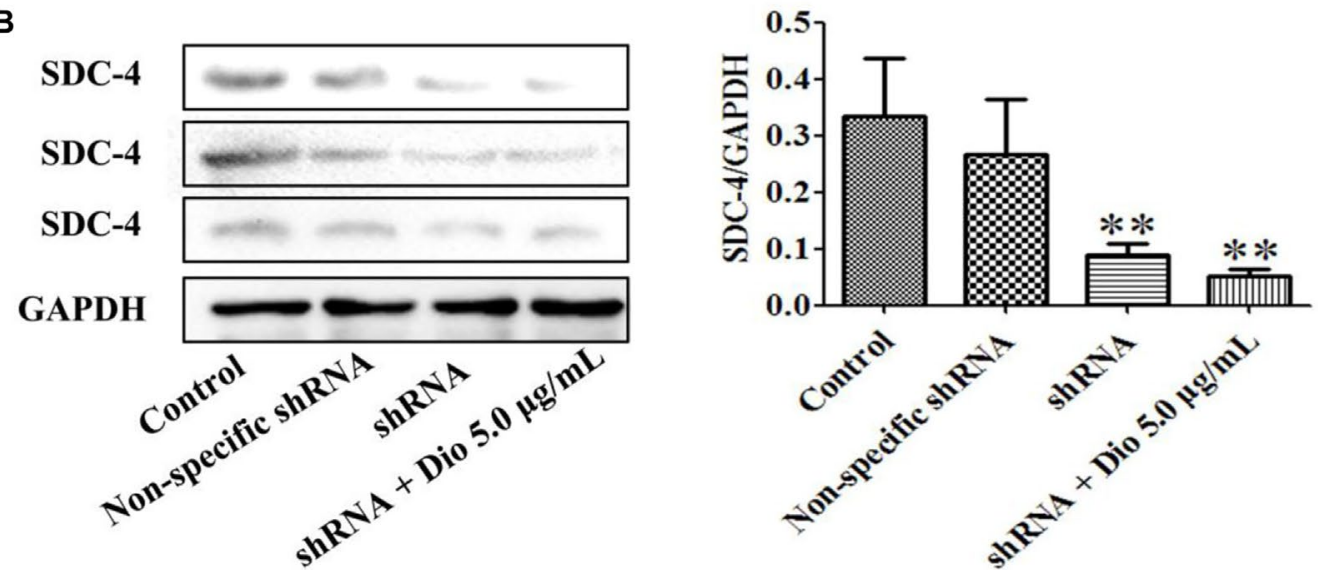

C
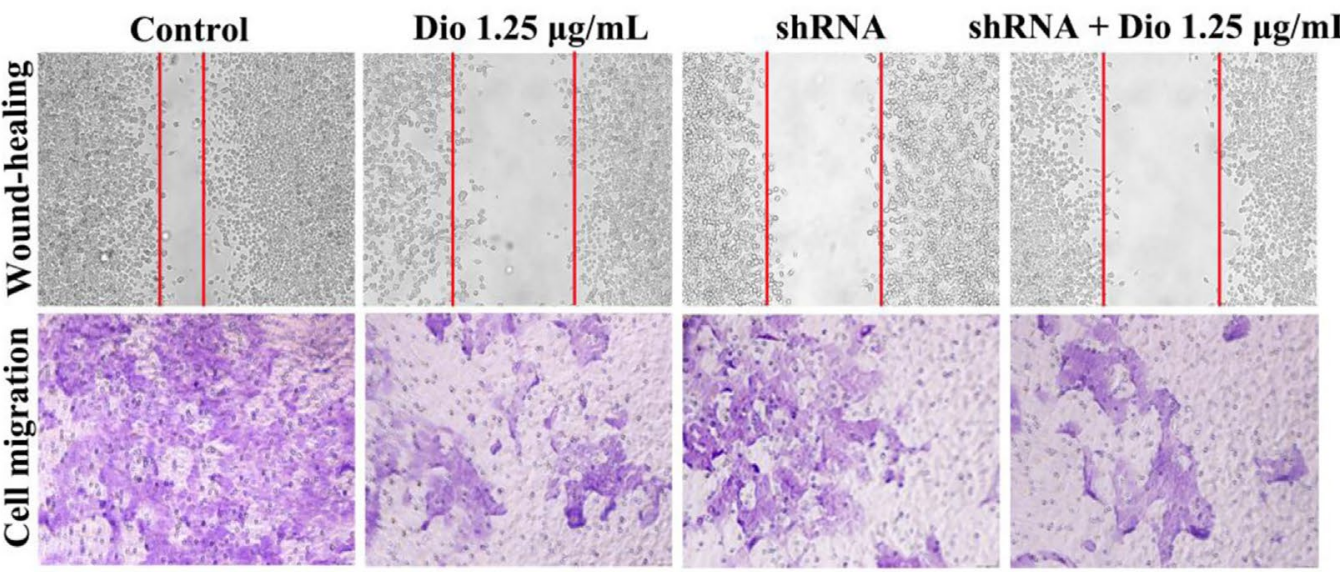

D
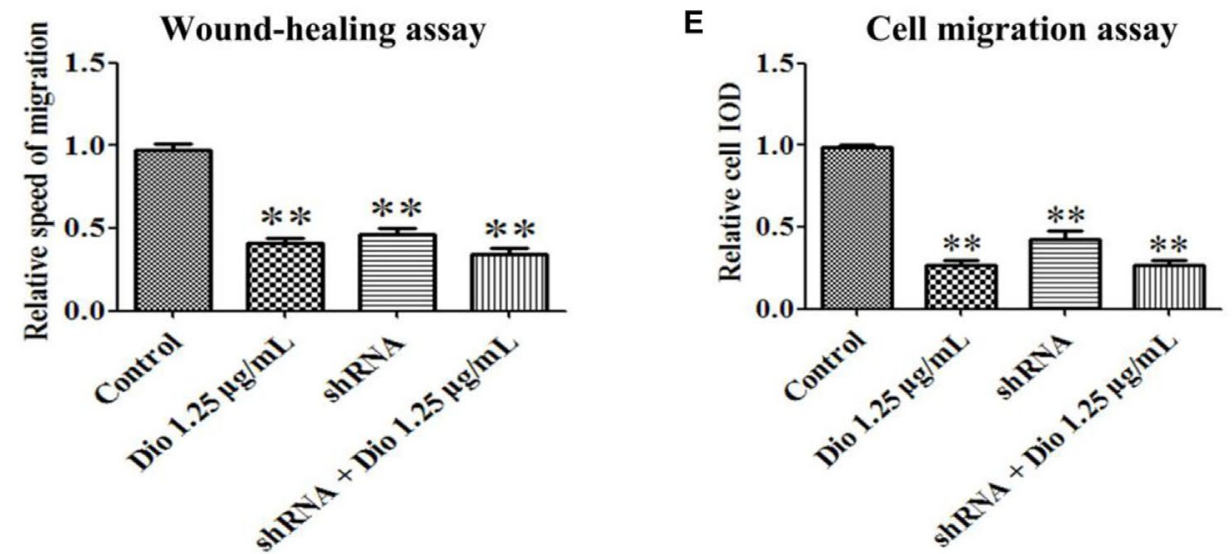

FIGURE 6 | Effects of SDC-4 shRNA and dioscin on SDC-4 expression. Effects of dioscin on SDC-4 level based on immunofluorescence assay ( $\times 400$ original magnification) (A) and western blotting assay (B) in HSC-T6 cells. (C-E) Wound-healing and cell migration assays of HSC-T6 cells treated by dioscin or SDC-4 shRNA. Data are presented as mean $\pm \mathrm{SD}(n=3)$. ${ }^{\star} p<0.05$ and ${ }^{\star *} p<0.01$ compared with control group. 